\title{
PENERAPAN HUKUM MORTALITA MAKEHAM UNTUK PENENTUAN NILAI CADANGAN PREMI ASURANSI JOINT LIFE DENGAN METODE FACKLER
}

\author{
Miftaahul Jannah ${ }^{1 \S}$, Agus Supriatna ${ }^{2}$, Riaman $^{3}$ \\ ${ }^{1}$ Universitas Padjadjaran [Email: miftaahul16001@mail.unpad.ac.id] \\ ${ }^{2}$ Universitas Padjadjaran [Email: agus.supriatna@unpad.ac.id] \\ ${ }^{3}$ Universitas Padjadjaran [Email: riaman@unpad.ac.id] \\ ${ }^{\S}$ Corresponding Author
}

\begin{abstract}
Joint life insurance is life insurance with an amount of more than one person, where the benefits are paid when one of the insured dies. The possibility of insurance companies will suffer losses if the claims that occur are more than predicted, so the premium reserve calculation is required. In this study, reserves were calculated using the Fackler method based on the Indonesian Mortality Table 2011 and the Makeham Assumption Mortality Table. The Indonesian Mortality Table 2011 was analyzed for the estimated parameters contained in the Makeham Assumption Mortality Table. Then the premium calculation and premium reserve calculation are done using the Fackler method based on the Makeham Assumption Mortality Table and the comparison uses the Indonesian Mortality Table 2011. The results of the calculation of the premiums based on the Makeham Assumption Mortality Table are greater than using the Indonesia Mortality Table 2011, while the premium reserve results are greater using the Indonesian Mortality Table 2011 than using the Makeham Assumption Mortality Table. This is because the chances of survival based on the Makeham Assumption Mortality Table are smaller than the Indonesian Mortality Table 2011.
\end{abstract}

Keywords: Joint Life Insurance, Premium Reserves, Fackler Method, Makeham Assumption.

\section{PENDAHULUAN}

Dalam menjalani hidup, kita tidak bisa lepas dari yang namanya risiko. Perjalanan hidup tidak selalu mulus sesuai yang kita harapkan. Hal yang tidak diinginkan bisa saja terjadi mempengaruhi kehidupan kita. Kita tidak akan tahu kapan musibah atau kecelakaan akan menimpa kita Bila kini kita sehat, suatu hari nanti bisa saja jatuh sakit, begitu juga usia manusia yang memiliki batas akhir. Berbagai risiko yang meliputi hidup baik yang bisa terjadi pada diri kita sendiri maupun pada asetaset yang kita miliki, seringkali menimbulkan dampak finansial. Sebenarnya, risiko-risiko finansial tersebut bisa dikelola lebih baik melalui asuransi. Melalui asuransi, risiko finansial dapat dialihkan ke pihak ketiga, yaitu perusahaan asuransi. Jadi, ketika terjadi risiko, biaya-biaya yang terkait dengan risiko tersebut ditangggung oleh penyedia asuransi.

Asuransi jiwa merupakan suatu yang memberikan pembayaran sejumlah uang tertentu atas kematian tertanggung kepada ahli waris atau orang yang berhak menerimanya sesuai dengan ketentuan dalam polis asuransi, sejumlah uang yang dibayarkan kepada tertanggung tersebut berupa uang pertanggungan (Bowers, 1997). Terdapat dua jenis asuransi jiwa berdasarkan jumlah tertanggungnya, yaitu asuransi jiwa perorangan dan asuransi jiwa gabungan. Pada asuransi jiwa gabungan berdasarkan jangka waktu pembayaran preminya dibagi menjadi asuransi joint life dan last survivor. Asuransi joint life, yaitu premi dibayarkan sampai kematian pertama dari salah seorang di antara kedua tertanggung dan saat itu juga dibayarkan sejumlah uang santunan dari penanggung kepada tertanggung (Frostig, 2003). Sedangkan berdasarkan jangka waktu perlindungannya asuransi jiwa dibagi menjadi tiga, yaitu asuransi jiwa seumur hidup, asuransi jiwa berjangka dan asuransi jiwa endowment. 
Setelah mengikuti asuransi, maka nasabah harus membayar premi sesuai dengan polis yang telah disetujui agar mendapatkan manfaat asuransi. Dari mulai diterimanya premi tersebut akan diperoleh pendapatan dari bunga secara terus menerus sehingga besar uang tersebut bertambah besar, dari uang inilah dilakukan pembayaran uang pertanggungan dikarenakan berbagai sebab (misal meninggal). Biasanya dipertengahan jangka pertanggungan pendapatan yang diperoleh lebih besar dari pengeluaran, selisih yang diperoleh ini merupakan cadangan perusahaan (Futami, 1993).

Menurut Destriani dan Mara (2014), tidak sedikit perusahaan jasa asuransi jiwa yang mengalami kerugian dikarenakan tidak mampu membayar santunan kepada tertanggung. Hal ini disebabkan jumlah klaim yang diajukan oleh tertanggung harus dibayar melebihi jumlah klaim yang diprediksi sebelumnya. Keadaan seperti ini dapat diantisipasi jika perusahaan memiliki dana cadangan yang telah dipersiapkan dan diperhitungkan dengan tepat.

Menentukan cadangan dapat dihitung dengan menggunakan beberapa metode. Dalam menentukan cadangan premi diperlukan nilai tunai anuitas hidup awal, premi tunggal, dan premi tahunan. Fungsi-fungsi pada aktuaria dapat dihitung dengan menggunakan tabel mortalita dan pendekatan hukum mortalita terhadap tabel mortalita. Pendekatan dengan hukum mortalita digunakan karena hasil dari pendekatan tersebut berbentuk kontinu sehingga praktis dalam penggunaannya (Bowers, 1997).

Pada penelitian sebelumnya, telah dibahas mengenai perhitungan nilai akumulasi anuitas berdasarkan distribusi Makeham oleh Nilwan dan Azhar (2015). Kemudian oleh Ni Komang, dkk (2018) telah dibahas mengenai penentuan cadangan premi asuransi joint life, namun penelitian tersebut menggunakan tingkat suku bunga berubah secara stokastik. Selain itu juga telah dibahas oleh Anggrita, dkk (2015) tentang perhitungan cadangan premi mengunakan metode Fackler, namun penelitian tersebut dikhususkan untuk satu orang tertanggung saja. Pada penelitian ini akan dibahas tentang cadangan premi pada asurani joint life endowment dengan metode yang digunakan adalah metode Fackler dengan jumlah tertanggung sejumlah dua orang dan berdasarkan asumsi Makeham.

\section{Tingkat Bunga}

Bunga adalah pembayaran yang dilakukan oleh peminjam uang sebagai balas jasa atas pemakaian uang yang dipinjam (Futami, 1993). Perhitungan bunga terbagi menjadi buga sederhana dan bunga majemuk. Dalam bunga majemuk didefinisikan suatu fungsi $v$ sebagai berikut:

$$
v=\frac{1}{1+i}
$$

\section{Simbol Komutasi}

Berdasarkan Futami (1994), simbol-simbol komutasi pada asuransi joint life didefinisikan secara analog dengan simbol-simbol komutasi pada asuransi jiwa perorangan yaitu:

$$
\begin{gathered}
D_{x y}=v^{\frac{x+y}{2}} l_{x y} \\
N_{x y}=D_{x y}+D_{x+1, y+1}+D_{x+2, y+2}+\ldots+D_{\omega \omega}=\sum_{t=0}^{\omega} D_{x+t, y+t} \\
C_{x y}=v^{\frac{x+y}{2}+1} d_{x y} \\
M_{x y}=C_{x y}+C_{x+1, y+1}+C_{x+2, y+2}+\ldots+C_{\omega \omega}=\sum_{t=0}^{\omega} C_{x+t, y+t}
\end{gathered}
$$

\section{Tabel Mortalita}

Tabel tingkat kematian atau yang disebut dengan tabel mortalita merupakan tabel yang diperoleh dari hasil observasi mengenai tingkat kematian berdasarkan kelompok umur tertentu (Futami, 1993). Tabel mortalita gabungan merupakan tabel tingkat kematian gabungan dari usia $x$ tahun dan usia $y$ tahun, dengan asumsi $x$ dan $y$ saling bebas (Bowers, 1997).

Jika $x$ dan $y$ menyatakan usia peserta asurasi, maka $l_{x y}$ merupakan fungsi gabungan dari orang berusia $x$ dan $y$, sehingga berlaku:

$$
l_{x y}=l_{x} l_{y}
$$

Jumlah orang meninggal dalam satu tahun dinyatakan dengan fungsi sebagai berikut:

$$
d_{x y}=l_{x y}-l_{x+1, y+1}
$$

Peluang dari pemegang polis berusia $x$ tahun dan $y$ tahun akan bertahan hidup dalam jangka waktu $t$ tahun kemudian dinotasikan dengan ${ }_{t} p_{x y}$ dan dirumuskan sebagai berikut:

$$
{ }_{t} p_{x y}={ }_{t} p_{x t} p_{y}=\frac{l_{x+t}}{l_{x}} \frac{l_{y+t}}{l_{y}}=\frac{l_{x+t} l_{y+t}}{l_{x} l_{y}}
$$




$$
=\frac{l_{x+t, y+t}}{l_{x y}}
$$

Peluang dari pemegang polis berusia $x$ tahun dan $y$ tahun akan meninggal dalam jangka waktu $t$ tahun dinotasikan dengan ${ }_{t} q_{x y}$ dan dirumuskan sebagai berikut:

$$
{ }_{t} q_{x y}=1-{ }_{t} p_{x y}=1-{ }_{t} p_{x t} p_{y}
$$

\section{Anuitas Joint Life}

Anuitas Joint Life adalah suatu kontrak anuitas yang terdiri dari dua tertanggung atau lebih, di mana pembayaran terhenti apabila salah satu tertanggung meninggal dunia.

Nilai sekarang anuitas awal joint life berjangka $n$ tahun untuk pemegang polis berusia $x$ dan $y$ tahun adalah

$$
\ddot{a}_{x y: n \mid}=\sum_{t=0}^{n-1} v_{t}^{t} p_{x y}
$$

Nilai sekarang anuitas akhir joint life berjangka $n$ tahun untuk pemegang polis berusia $x$ dan $y$ tahun adalah

$$
a_{\overline{x y: n}}=\sum_{t=1}^{n} v_{t}^{t} p_{x y}
$$

Persamaan anuitas joint life tersebut dapat digunakan dalam perhitungan premi asuransi joint life berjangka maupun endowment.

\section{Premi}

Premi adalah sejumlah uang yang dibayarkan pemegang polis kepada perusahaan untuk mendapatkan manfaat sebagai imbalannya (Promislow, 2011). Premi yang dibayarkan secara sekaligus atau dibayarkan hanya satu kali saja pada rentang waktu asuransi yang ditetapkan disebut premi tunggal. Premi juga dapat dibayarkan secara berkala tiap awal tahun yang disebut premi tahunan, atau bisa juga dibayarkan tiap awal bulan dan awal semester.

Premi tunggal bersih asuransi joint life endowment berjangka $n$ tahun untuk tertanggung berusia $x$ dan $y$ tahun dengan santunan $R$ rupiah adalah:

$$
A_{x y: n \mid}=R \frac{M_{x y}-M_{x+n, y+n}+D_{x+n, y+n}}{D_{x y}}
$$

Persamaan premi bersih tahunan asuransi joint life endowment dapat dinyatakan dengan rumus berikut:

$$
P_{\overline{x y: n \mid}}=\frac{A_{x y: n}}{\ddot{a} \overline{x y: n}}
$$

\section{Cadangan Premi}

Menurut Futami (1993), cadangan secara teori adalah besarnya uang yang ada pada perusahaan dalam jangka waktu pertanggungan. Cadangan premi dapat dihitung dengan dua metode dari sudut pandangnya, yaitu metode retrospektif dan metode prospektif. Cadangan retrospektif, yaitu perhitungan cadangan berdasarkan jumlah total pendapatan di waktu lampau sampai saat dilakukan perhitungan cadangan dikurangi dengan jumlah pengeluaran di waktu lampau untuk setiap pemegang polis. Sedangkan yang dimaksud dengan cadangan prospektif adalah besar cadangan yag berorientasi pada pengeluaran di waktu yang akan datang atau dengan pengertian lain, yaitu perhitungan cadangan berdasarkan nilai sekarang dari semua pengeluaran di waktu yang akan datang dikurangi dengan nilai sekarang total pendapatan di waktu yang akan datang untuk setiap pemegang polis. Kedua metode tersebut mengahasilkan perhitungan cadangan premi yang sama.

\section{Hukum Mortalita Makeham}

Menurut Futami (1993), percepatan mortalita (force of mortality) dinotasikan dengan $\mu_{x}$, yaitu:

$$
\mu_{x}=-\frac{d \log l_{x}}{d x}
$$

pada tahun 1860, W.M. Makeham mengemukakan teori yang merupakan penyempurnaan dari teori sebelumnya yaitu Teori Gompertz. Sebelumnya akan dibahas terlebih dahulu definisi dari distribusi Gompertz.

\section{Definisi 1:}

Distribusi Gompertz dinotasikan dengan $G(x \mid \mu, \sigma)$ di mana $\mu$ adalah rata-rata dan $\sigma$ adalah standar deviasi, didefinisikan sebagai berikut [8]:

$$
G(x \mid \mu, \sigma)=W\left(\frac{x-a}{b}\right)
$$

dengan $W(x)=1-e^{-e^{x}}$ dan konstanta $a$ dan $b$ memenuhi

$$
\sigma=\left(\frac{\pi}{\sqrt{6}}\right) b \text { dan } \mu=a-b \gamma
$$

$B$ dan $c$ adalah konstanta Gompertz yang nilainya dapat dicari menggunakan distribusi Gompertz karena $G(x \mid \mu, \sigma)$ dapat dinyatakan 
dengan

$$
G(x \mid \mu, \sigma)=1-g^{c^{x}}
$$

$$
g=e^{-e^{\frac{-a}{b}}} \text { dan } c=e^{\frac{1}{b}}
$$

W.M. Makeham menyatakan percepatan mortalitanya sebagai berikut:

sehingga didapat:

$$
\mu_{x}=A+B c^{x}
$$

$$
\begin{gathered}
l_{x}=k s^{x} g^{c^{x}} \\
{ }_{t} p_{x}=s^{t} g^{c^{x}\left(c^{t}-1\right)} \\
{ }_{t} q_{x}=1-{ }_{t} p_{x} 1-s^{t} g^{c^{x}\left(c^{t}-1\right)}
\end{gathered}
$$

\section{Metode Fackler}

Rumus pada metode Fackler merupakan turunan dari rumus umum cadangan retrospektif, maka metode Fackler adalah metode untuk menghitung nilai cadangan retrospektif. Rumus umum metode Fackler untuk asuransi joint ife sebagai berikut:

$$
\begin{aligned}
& \quad{ }_{t+1} V=\left({ }_{t} V+P\right) u_{x+t, y+t}-k_{x+t, y+t} \\
& \text { dengan } u_{x+t, y+t}=\frac{D_{x+t, y+t}}{D_{x+t+1, y+t+1}} \\
& \text { dan } k_{x+t, y+t}=\frac{C_{x+t, y+t}}{D_{x+t+1, y+t+1}}
\end{aligned}
$$

untuk cadangan tahun pertama dapat dihitung sebagai berikut:

$$
{ }_{1} V=P \cdot u_{x, y}-k_{x, y}
$$

\section{METODE PENELITIAN}

Data yang digunakan dalam penelitian ini adalah data simulasi. Pengolahan data pada penelitian ini menggunakan software Microsoft Excel. Langkah-langkah yang dilakukan pada penelitian ini adalah:

1. Menentukan usia pemegang polis, tingkat bunga, dan jangka waktu pertanggungan.

2. Menentukan estimasi parameter dari hukum mortalita Makeham yang akan digunakan dalam pembentukan Tabel Mortalita Asumsi Makeham.

3. Membuat Tabel Mortalita Asumsi Makeham.

4. Menghitung anuitas hidup berjangka asuransi joint life endowment berdasarkan Tabel Mortalita Asumsi Makeham dan Tabel Mortalita Indonesia (TMI) 2011 dengan persamaan (10).

5. Menghitung premi tunggal bersih asuransi joint life endowment berdasarkan Tabel Mortalita Asumsi Makeham dan Tabel Mortalita Indonesia (TMI) 2011 dengan persamaan (12).
6. Menghitung premi tahunan asuransi joint life endowment berdasarkan Tabel Mortalita Asumsi Makeham dan Tabel Mortalita Indonesia (TMI) 2011 dengan persamaan (13).

7. Menghitung cadangan premi menggunakan metode Fackler berdasarkan Tabel Mortalita Asumsi Makeham dan Tabel Mortalita Indonesia (TMI) 2011 dengan persamaan (23) dan (24).

\section{HASIL DAN PEMBAHASAN}

\subsection{Data Penelitian}

Data yang digunakan dalam penelitian ini adalah data simulasi, yaitu terdapat 5 pasangan pemegang polis (pria dan wanita). Besarnya uang santunan tiap pemegang polis disamakan, yaitu sebesar Rp100.000.000,00 dengan masa pertanggungan asuransi setiap pasangan adalah sama yaitu selama 20 tahun. Tingkat bunga yang digunakan adalah 5\%. Berikut data pemegang polis yang disajikan dalam Tabel 1 .

Tabel 1. Data Pemegang Polis

\begin{tabular}{|c|c|c|}
\hline No. & Pemegang Polis & Usia \\
\hline 1 & Irfan \& Dhea & $28 \& 25$ \\
\hline 2 & Vicky \& Eva & $32 \& 29$ \\
\hline 3 & Rizky \& Dinar & $35 \& 30$ \\
\hline 4 & Keanu \& Bilqis & $42 \& 40$ \\
\hline 5 & Zio \& Lubna & $45 \& 43$ \\
\hline
\end{tabular}

\subsection{Tabel Mortalita Asumsi Makeham}

Berdasarkan persamaan hukum mortalita Makeham maka dapat dihitung konstanta Makeham untuk Tabel Mortalita Indonesia (TMI) 2011. Sebelumnya tentukan terlebih dahulu rata-rata $(\mu)$ dan standar deviasi $(\sigma)$, dengan menggunakan Microsoft Excel maka diperoleh $\mu=55,5$ dan $\sigma=32,33032632$. Kemudian dapat dicari nilai $a$ dan $b$ sehingga diperoleh nilai $a=70,05036706$ dan $b=$ 25,20785202, kemudian dicari nilai $g, c$, dan s. Dengan menggunakan Microsoft Excel maka diperoleh nilai $g=0,939783143, \quad c=$ 1,040467549 dan $s=0,998121766$ yang dapat digunakan dalam pembentukan Tabel Mortalita Asumsi Makeham.

Selanjutnya, berdasarkan Tabel Mortalita Indonesia (TMI) 2011 ditentukan batas atas usia kohor $(\omega)$ adalah 111 dan jumlah kohor 
awal $\left(l_{0}\right)$ adalah 100000. Dengan menggunakan persamaan (20), dapat dihitung jumlah orang yang hidup pada usia $x=1$ tahun,

$$
\begin{aligned}
l_{1} & =k s^{1} g^{c^{1}} \\
& =93566,34658 \approx 93566
\end{aligned}
$$

Berdasarkan perhitungan di atas, artinya jumlah orang yang hidup pada usia 1 tahun adalah 93566 orang, kemudian dilakukan perhitungan sampai $x=111$. Sedangkan untuk mendapatkan nilai ${ }_{t} p_{x}$ dan ${ }_{t} q_{x}$ dapat dihitung dengan persamaan (21) dan (22) sebagai berikut:

$$
\begin{aligned}
{ }_{1} p_{1} & =s^{1} g^{c^{1}\left(c^{1}-1\right)} \\
& =0,995515098 \\
\text { dan } & \\
{ }_{1} q_{1} & =1-{ }_{1} p_{1} \\
& =1-0,995515098 \\
& =0,004383647
\end{aligned}
$$

Berdasarkan perhitungan di atas, artinya peluang orang yang berusia 1 tahun akan tetap hidup selama 1 tahun lagi adalah 0,995515098 sedangkan peluang orang yang berusia 1 tahun akan meninggal dalam jangka waktu 1 tahun kemudian adalah 0,004383647. Dengan menggunakan cara yang sama dilakukan perhitungan sampai $x=111$ menggunakan Microsoft Excel, sehingga dapat dibentuk Tabel Mortalita Asumsi Makeham.

\subsection{Perhitungan Anuitas Joint Life}

Anuitas hidup awal joint life berjangka $n$

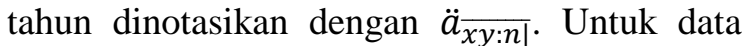
pada Tabel 1 dapat dihitung anuitas hidup menggunakan persamaan (10), maka perhitungan anuitas hidup untuk pemegang polis ke-1 berdasarkan TMI 2011 sebagai berikut:

$\ddot{a}_{\overline{28,25: 20 \mid}}=\sum_{t=0}^{19} v^{t}{ }_{t} p_{28,25}=12,92291853$

Dengan menggunakan cara yang sama,

\begin{tabular}{|c|c|c|}
\hline \multirow[b]{2}{*}{$\begin{array}{c}\text { Pemegang } \\
\text { Polis }\end{array}$} & \multicolumn{2}{|c|}{$\ddot{a}_{\overline{x y: n \mid}}$} \\
\hline & TMI 2011 & $\begin{array}{c}\text { Tabel } \\
\text { Mortalita } \\
\text { Asumsi } \\
\text { Makeham }\end{array}$ \\
\hline $\begin{array}{c}\text { Irfan \& } \\
\text { Dhea }\end{array}$ & 12,92291853 & 11,10248829 \\
\hline $\begin{array}{c}\text { Vicky \& } \\
\text { Eva }\end{array}$ & 12,86371694 & 10,86162113 \\
\hline $\begin{array}{c}\text { Risky \& } \\
\text { Dinar }\end{array}$ & 12,8037363 & 10,72468419 \\
\hline $\begin{array}{c}\text { Keanu \& } \\
\text { Bilqis }\end{array}$ & 12,41672093 & 10,08433906 \\
\hline $\begin{array}{l}\text { Zio \& } \\
\text { Lubna }\end{array}$ & 12,17269686 & 9,820263794 \\
\hline
\end{tabular}
maka dapat dihitung anuitas hidup untuk pemegang polis lainnya, hasilnya dapat dilihat pada Tabel 2.
Tabel 2. Anuitas Hidup Asuransi Joint Life Endowment

\subsection{Perhitungan Premi Tunggal Bersih Asuransi Joint Life Endowment}

Premi tunggal bersih yang dinotasikan dengan $A_{\overline{x y: n} \mid}$ dapat dihitung menggunakan persamaan (12), maka perhitungan premi tunggal bersih untuk pemegang polis ke-1 berdasarkan TMI 2011 sebagai berikut:

$$
\begin{aligned}
A_{\overline{28,25: 20 \mid}} & =10^{8} \frac{M_{28,25}-M_{48,45}+D_{48,45}}{D_{28,25}} \\
& =38.462 .292,66
\end{aligned}
$$

Dengan menggunakan cara yang sama, maka dapat dihitung premi tunggal bersih untuk pemegang polis lainnya, hasilnya dapat dilihat pada Tabel 3.

Tabel 3. Premi Tunggal Bersih Asuransi Joint Life Endowment

\begin{tabular}{|c|c|c|}
\hline \multirow{2}{*}{$\begin{array}{c}\text { Pemegang } \\
\text { Polis }\end{array}$} & TMI 2011 & $\begin{array}{c}\text { Tabel } \\
\text { Mortalita } \\
\text { Asumsi } \\
\text { Makeham }\end{array}$ \\
\cline { 2 - 3 } & $38.462 .292,66$ & $47.131 .008,16$ \\
\hline $\begin{array}{c}\text { Irfan \& } \\
\text { Dhea }\end{array}$ & $38.744 .205,09$ & $48.277 .994,64$ \\
\hline $\begin{array}{c}\text { Vicky \& } \\
\text { Eva }\end{array}$ & $39.029 .827,02$ & $48.930 .075,3$ \\
\hline $\begin{array}{c}\text { Risky \& } \\
\text { Dinar }\end{array}$ & $40.872 .757,63$ & $51.979 .337,83$ \\
\hline $\begin{array}{c}\text { Keanu \& } \\
\text { Bilqis }\end{array}$ & $42.034 .776,8$ & $53.236 .839,07$ \\
\hline $\begin{array}{c}\text { Zio \& } \\
\text { Lubna }\end{array}$ &
\end{tabular}




\subsection{Perhitungan Premi Bersih Tahunan Asuransi Joint Life Endowment}

Premi bersih tahunan yang dinotasikan dengan $P_{\overline{x y: n} \mid}$ dapat dihitung menggunakan persamaan (13), maka perhitungan premi bersih tahunan untuk pemegang polis ke-1 berdasarkan TMI 2011 sebagai berikut:

$P_{\overline{28,25: 20 \mid}}=\frac{A_{\overline{28,25: 20}}}{\ddot{a}_{\overline{28,25: 20}}}=2.976 .285,316$

Dengan menggunakan cara yang sama, maka dapat dihitung premi bersih tahunan untuk pemegang polis lainnya, hasilnya dapat dilihat pada Tabel 4.

Tabel 4. Premi Bersih Tahunan Asuransi Joint Life Endowment

\begin{tabular}{|c|c|c|}
\hline \multirow{2}{*}{$\begin{array}{c}\text { Pemegang } \\
\text { Polis }\end{array}$} & \multicolumn{2}{|c|}{$P_{\overline{x y: n} \mid}$} \\
\cline { 2 - 3 } & TMI 2011 & $\begin{array}{c}\text { Tabel } \\
\text { Mortalita } \\
\text { Asumsi } \\
\text { Makeham }\end{array}$ \\
\hline $\begin{array}{c}\text { Irfan \& } \\
\text { Dhea }\end{array}$ & $2.976 .285,316$ & $4.245 .085,151$ \\
\hline $\begin{array}{c}\text { Vicky \& } \\
\text { Eva }\end{array}$ & $3.011 .898,137$ & $4.444 .824,034$ \\
\hline $\begin{array}{c}\text { Risky \& } \\
\text { Dinar }\end{array}$ & $3.048 .315,438$ & $4.562 .379,129$ \\
\hline $\begin{array}{c}\text { Keanu \& } \\
\text { Bilqis }\end{array}$ & $3.291 .751,329$ & $5.154 .461,542$ \\
\hline $\begin{array}{c}\text { Zio \& } \\
\text { Lubna }\end{array}$ & $3.453 .201,642$ & $5.421 .121,081$ \\
\hline
\end{tabular}

\subsection{Perhitungan Cadangan Premi}

Setiap tahunnya ditentukan nilai cadangan premi asurani joint life endowment dari awal tahun kontrak hingga akhir jangka pertanggungan. Cadangan premi tahun pertama dihitung menggunakan persamaan (24) dan tahun selanjutnya dihitung menggunakan persamaan (23), berikut perhitungan cadangan premi untuk pemegang polis ke-1 berdasarkan TMI 2011:

Cadangan tahun ke-1

$$
\begin{aligned}
{ }_{1} V & =P \cdot u_{28,25}-k_{28,25} \\
& =(2.976 .285,316)(1,051229608)+ \\
-10^{8} & (0,001171055) \\
& =3.011 .653,769
\end{aligned}
$$

Cadangan tahun ke-2

$$
\begin{gathered}
{ }_{2} V=\left({ }_{1} V+P\right) u_{29,26}-k_{29,26} \\
=(3.011 .653,769+ \\
+2.976 .285,316(1,051240121)+ \\
-10^{8}(0,001181068) \\
\quad=6.176 .655,041
\end{gathered}
$$

Dengan menggunakan cara yang sama maka dapat dihitung cadangan premi untuk pemegang polis lainya sampai tahun ke-20 berdasarkan TMI 2011 dan Tabel Mortalita Asumsi Makeham. Untuk hasilnya dapat dilihat pada Tabel 5 sampai Tabel 9 yang berisi cadangan premi untuk masing-masing pemegang polis dari tahun pertama sampai akhir tahun polis.

Tabel 5. Cadangan Premi Pemegang Polis ke-1

\begin{tabular}{|c|c|c|}
\hline $\mathrm{t}$ & $\begin{array}{c}\text { TMI 2011 } \\
\text { (Rupiah) }\end{array}$ & $\begin{array}{c}\text { Tabel Mortalita } \\
\text { Asumsi Makeham } \\
\text { (Rupiah) }\end{array}$ \\
\hline 1 & $3.011 .653,769$ & $2.705 .680,763$ \\
\hline 2 & $6.176 .655,041$ & $5.543 .674,85$ \\
\hline 3 & $9.500 .209,268$ & $8.524 .495,225$ \\
\hline 4 & $12.988 .978,62$ & $11.659 .791,05$ \\
\hline 5 & $16.651 .875,93$ & $14.962 .488,91$ \\
\hline 6 & $20.499 .895,22$ & $18.446 .953,58$ \\
\hline 7 & $24.542 .121,79$ & $22.129 .171,12$ \\
\hline 8 & $28.786 .834,46$ & $26.026 .957,97$ \\
\hline 9 & $33.243 .839,32$ & $30.160 .199,95$ \\
\hline 10 & $37.923 .782,32$ & $34.551 .126,06$ \\
\hline 11 & $42.838 .224,45$ & $39.224 .622,52$ \\
\hline 12 & $47.996 .600,1$ & $44.208 .593,79$ \\
\hline 13 & $53.411 .174,05$ & $49.534 .378,28$ \\
\hline 14 & $59.097 .279,61$ & $55.237 .227,88$ \\
\hline 15 & $65.072 .531,97$ & $61.356 .862,34$ \\
\hline 16 & $71.355 .944,96$ & $67.938 .111,3$ \\
\hline 17 & $77.966 .947,12$ & $75.031 .659,42$ \\
\hline 18 & $84.927 .147,37$ & $82.694 .913,04$ \\
\hline 19 & $92.261 .809,42$ & $90.993 .010,11$ \\
\hline 20 & 100.000 .000 & 100.000 .000 \\
\hline
\end{tabular}


Tabel 6. Cadangan Premi Pemegang Polis ke-2

\begin{tabular}{|c|c|c|}
\hline $\mathrm{t}$ & $\begin{array}{c}\text { TMI 2011 } \\
\text { (Rupiah) }\end{array}$ & $\begin{array}{c}\text { Tabel Mortalita } \\
\text { Asumsi Makeham } \\
\text { (Rupiah) }\end{array}$ \\
\hline 1 & $3.032 .597,771$ & $2.67 .8425,256$ \\
\hline 2 & $6.217 .343,177$ & $5.484 .876,196$ \\
\hline 3 & $9.561 .420,544$ & $8.430 .096,004$ \\
\hline 4 & $13.070 .768,94$ & $11.526 .067,78$ \\
\hline 5 & $16.752 .823,57$ & $14.786 .177,44$ \\
\hline 6 & $20.615 .678,3$ & $18.225 .400,29$ \\
\hline 7 & $24.668 .145,26$ & $21.860 .515,04$ \\
\hline 8 & $28.915 .550,07$ & $25.710 .349,87$ \\
\hline 9 & $33.365 .983,64$ & $29.796 .065,69$ \\
\hline 10 & $38.030 .799,26$ & $34.141 .482,93$ \\
\hline 11 & $42.923 .719,78$ & $38.773 .459,35$ \\
\hline 12 & $480.595 .66,84$ & $43.722 .327,46$ \\
\hline 13 & $53.452 .024,04$ & $49.022 .402,35$ \\
\hline 14 & $59.115 .564,49$ & $54.712 .572,06$ \\
\hline 15 & $65.067 .733,68$ & $60.836 .985,81$ \\
\hline 16 & $71.329 .548,51$ & $67.445 .857,78$ \\
\hline 17 & $77.924 .698,28$ & $74.596 .407,98$ \\
\hline 18 & $84.880 .006,69$ & $82.353 .966,36$ \\
\hline 19 & $92.226 .197,58$ & $90.793 .271,2$ \\
\hline 20 & 100.000 .000 & 100.000 .000 \\
\hline & & \\
\hline
\end{tabular}

Tabel 7. Cadangan Premi Pemegang Polis ke-3

\begin{tabular}{|c|c|c|}
\hline $\mathrm{t}$ & $\begin{array}{c}\text { TMI 2011 } \\
\text { (Rupiah) }\end{array}$ & $\begin{array}{c}\text { Tabel Mortalita } \\
\text { Asumsi Makeham } \\
\text { (Rupiah) }\end{array}$ \\
\hline 1 & $3.060 .216,159$ & $2.663 .225,177$ \\
\hline 2 & $6.267 .788,821$ & $5.451 .957,331$ \\
\hline 3 & $9.629 .241,993$ & $8.377 .058,982$ \\
\hline 4 & $13.153 .439,18$ & $11.450 .691,3$ \\
\hline 5 & $16.846 .438,6$ & $14.686 .489,82$ \\
\hline 6 & $20.715 .146,34$ & $18.099 .766,32$ \\
\hline 7 & $24.764 .395,64$ & $21.707 .741,46$ \\
\hline 8 & $29.004 .676,61$ & $25.529 .813,09$ \\
\hline 9 & $33.448 .135,38$ & $29.587 .866,45$ \\
\hline 10 & $38.104 .798,51$ & $33.906 .633,48$ \\
\hline 11 & $42.986 .889,46$ & $38.514 .109,89$ \\
\hline 12 & $48.106 .767,11$ & $43.442 .040,23$ \\
\hline 13 & $53.478 .606,97$ & $48.726 .483,32$ \\
\hline 14 & $59.119 .700,62$ & $54.408 .472,75$ \\
\hline 15 & $65.050 .933,96$ & $60.534 .790,21$ \\
\hline 16 & $71.294 .673,99$ & $67.158 .873,03$ \\
\hline 17 & $77.877 .030,65$ & $74.341 .881,67$ \\
\hline 18 & $84.829 .568,18$ & $82.153 .958,56$ \\
\hline 19 & $92.189 .778,37$ & $90.675 .716,04$ \\
\hline 20 & 100.000 .000 & 100.000 .000 \\
\hline
\end{tabular}

Tabel 8. Cadangan Premi Pemegang Polis ke-4

\begin{tabular}{|c|c|c|}
\hline $\mathrm{t}$ & $\begin{array}{c}\text { TMI 2011 } \\
\text { (Rupiah) }\end{array}$ & $\begin{array}{c}\text { Tabel Mortalita } \\
\text { Asumsi Makeham } \\
\text { (Rupiah) }\end{array}$ \\
\hline 1 & $3.156 .339,937$ & $2.595 .390,876$ \\
\hline 2 & $6.447 .999,575$ & $5.303 .711,964$ \\
\hline 3 & $9.878 .279,989$ & $8.136 .260,788$ \\
\hline 4 & $13.450 .693,94$ & $11.105 .903,23$ \\
\hline 5 & $17.171 .684,88$ & $14.227 .313,49$ \\
\hline 6 & $21.048 .189,08$ & $17.517 .254,6$ \\
\hline 7 & $25.087 .148,42$ & $20.994 .907,06$ \\
\hline 8 & $29.296 .646,83$ & $24.682 .254,77$ \\
\hline 9 & $33.684 .269,45$ & $28.604 .539,38$ \\
\hline 10 & $38.261 .668,74$ & $32.790 .796,4$ \\
\hline 11 & 43.044 .066 & $37.274 .489,53$ \\
\hline 12 & $48.052 .580,26$ & $42.094 .263,05$ \\
\hline 13 & $53.309 .085,89$ & $47.294 .836,58$ \\
\hline 14 & $58.840 .070,77$ & $52.928 .072,23$ \\
\hline 15 & $64.677 .741,73$ & $59.054 .250,74$ \\
\hline 16 & $70.860 .334,92$ & $65.743 .601,93$ \\
\hline 17 & $77.432 .543,23$ & $73.078 .145,69$ \\
\hline 18 & $84.443 .559,97$ & $81.153 .912,97$ \\
\hline 19 & $91.946 .345,8$ & $90.083 .633,71$ \\
\hline 20 & 100.000 .000 & 100.000 .000 \\
\hline
\end{tabular}

Tabel 9. Cadangan Premi Pemegang Polis ke-5

\begin{tabular}{|c|c|c|}
\hline $\mathrm{t}$ & $\begin{array}{c}\text { TMI 2011 } \\
\text { (Rupiah) }\end{array}$ & $\begin{array}{c}\text { Tabel Mortalita } \\
\text { Asumsi Makeham } \\
\text { (Rupiah) }\end{array}$ \\
\hline 1 & $3.203 .286,787$ & $2.569 .191,554$ \\
\hline 2 & $6.529 .021,09$ & $5.245 .736,213$ \\
\hline 3 & $9.981 .461,456$ & $8.041 .045,643$ \\
\hline 4 & $13.564 .346,13$ & $10.968 .207,13$ \\
\hline 5 & $17.282 .058,93$ & $14.042 .252,11$ \\
\hline 6 & $21.137 .529,15$ & $17.280 .472,17$ \\
\hline 7 & $25.137 .399,78$ & $20.702 .791,99$ \\
\hline 8 & $29.291 .362,07$ & $24.332 .210,43$ \\
\hline 9 & $33.615 .000,11$ & $28.195 .323,69$ \\
\hline 10 & $38.123 .203,06$ & $32.322 .947,47$ \\
\hline 11 & $42.834 .675,69$ & $36.750 .858,78$ \\
\hline 12 & $47.773 .274,52$ & $41.520 .683,07$ \\
\hline 13 & $52.968 .478,86$ & $46.680 .958,02$ \\
\hline 14 & $58.456 .445,61$ & $52.288 .413,05$ \\
\hline 15 & $64.277 .309,99$ & $58.409 .512,95$ \\
\hline 16 & $70.472 .751,45$ & $65.122 .325,85$ \\
\hline 17 & $77.087 .369,94$ & $72.518 .790,89$ \\
\hline 18 & $84.171 .633,64$ & $80.707 .480,23$ \\
\hline 19 & $91.784 .893,12$ & $89.816 .974,17$ \\
\hline 20 & 100.000 .000 & 100.000 .000 \\
\hline
\end{tabular}




\section{KESIMPULAN}

Berdasarkan hasil penelitian yang sudah dilakukan dapat disimpulkan beberapa hal. Pertama, hasil simulasi penentuan premi asuransi joint life endowment menggunakan Tabel Mortalita Asumsi Makeham lebih besar dibandingkan dengan menggunakan Tabel Mortalita Indonesia (TMI) 2011. Hal ini disebabkan oleh peluang hidup berdasarkan Tabel Mortalita Asumsi Makeham lebih kecil dibandingkan Tabel Mortalita Indonesia (TMI) 2011. Kedua, hasil simulasi penentuan cadangan premi asuransi joint life endowment menggunakan Tabel Mortalita Indonesia (TMI) 2011 lebih besar dibandingkan dengan menggunakan Tabel Mortalita Asumsi Makeham. Hal ini disebabkan oleh jumlah orang yang hidup pada Tabel Mortalita Indonesia (TMI) 2011 lebih besar dibandingkan dengan Tabel Mortalita Asumsi Makeham.

Semakin banyak jumlah pemegang polis yang hidup pada usia $x$ tahun dan $y$ tahun maka semakin besar cadangan yang dibutuhkan. Selain itu, perhitungan cadangan premi menggunakan Tabel Mortalita Indonesia (TMI) 2011 dan Tabel Mortalita Asumsi Makeham menghasilkan nilai cadangan yang sama besar dengan uang pertanggungan pada akhir tahun polis.

\section{DAFTAR PUSTAKA}

Futami, T. 1993. Matematika Asuransi Jiwa Bagian I. Tokyo: Incorporated Foundation Oriental Life Insurance Cultural Development Center.

Futami, T. 1994. Matematika Asuransi Jiwa Bagian II. Tokyo: Incorporated Foundation Oriental Life Insurance Cultural Development Center.

Frostig, E. B. L., 2003. The Impact of Statistical Dependence on Multiple Life Insurance Program. Department of Statistics, University of Haifa.

Promislow, S. D. 2011. Fundamental of Actuarial Mathematics (Second ed.).United Kingdom: John Wiley and Sons Inc.
Bowers, N. L., Gerber, H. U., Hickman, J. C., Jones, D. A., \& Nesbit, C. J. 1997. Actuarial Mathematics. Illinois: The Society of Actuaries.

Willemse, W. J. \& Koppelaar, H. 2000. Knowledge Elicitation of Gompertz Law of Mortality. Scandinavian Actuarial Journal, 2: $168-179$.

Destriani, Satyahadewi, N. \& Mara, M.N.2014. Penentuan Nilai Cadangan Prospektif pada Asuransi Jiwa Seumur Hidup Menggunakan Metode New Jersey. Bulletin Ilmiah Mat.Stat danTerapannya (BIMASTER), 03, pp 7-12.

Sukanasih, N.K., Widana, I N., \& Jayanegara, K., 2018. Cadangan Premi Asuransi Joint Life dengan Suku Bunga Tetap dan Berubah Secara Stokastik. E-Jurnal Matematika. Vol. 7 (2), pp. 79-87.

Andiraja, N. \& Fadli, A., 2015. Nilai Akumulasi Anuitas Berjangka dengan Distribusi Makeham pada Status Hidup Gabungan. Jurnal Sains Matematikadan Statistika, Vol. 1, No.1.

Januarti, A., Lestari, R., \& Baqi, I.A. 2015. Perhitungan Cadangan Premi Tahunan pada Asuransi Jiwa Seumur Hidup dengan Menggunakan Metode Fackler. Jurnal Matematika UNAND. Vol 4,No.3, Hal.1- 6. 